\title{
Lucerne and other perennial legumes provide new options for rain fed livestock production in the Mediterranean-climate region of Chile
}

\author{
Carlos Ovalle ${ }^{1}$, Soledad Espinoza ${ }^{1}$, Viviana Barahona ${ }^{1}$, Macarena Gerding ${ }^{2}$, \\ Alan Humphries ${ }^{3}$, and Alejandro del Pozo ${ }^{4}$ \\ 'Instituto de Investigaciones Agropecuarias, INIA Quilamapu, Ave. Vicente Méndez 515, Chillán, Chile \\ ${ }^{2}$ Universidad de Concepción, Facultad de Agronomía. Ave. Vicente Méndez 595, Chillán, Chile. \\ ${ }^{3}$ South Australian Research and Development Institute (SARDI), Science Program Leader Livestock Feed \\ and Forage, GPO Box 397, Adelaide, Australia. \\ ${ }^{4}$ Universidad de Talca, Facultad de Ciencias Agrarias, Av. Lircay s/n, Talca, Chile.
}

\begin{abstract}
C. Ovalle, S. Espinoza, V. Barahona, M. Gerding, A. Humphries, and A. del Pozo. 2015. Lucerne and other perennial legumes provide new options for rainfed livestock production in the Mediterranean-climate region of Chile. Cien. Inv. Agr. 42(3): 461-474. In dryland Mediterranean environments, the productivity of annual legumes is low during autumn and winter, with plant senescence typically beginning by the middle of spring because of low soil water availability. Therefore, the use of deep-rooted perennial legumes may provide an alternative to annual legumes in regions with a soil moisture deficit. We evaluated the germplasm of new perennial legumes with deep rooting systems in two field experiments in the interior drylands of central Chile. In experiment 1 , sixteen genotypes of four perennial legume species, nine cultivars (cvs.) of Medicago sativa, two of Hedysarum coronarium, three of Lotus tenuis, and two of Lotus corniculatus were evaluated for three seasons (2012-2014). In experiment 2, eight additional genotypes from two perennial legume species ( $M$. sativa and $H$. coronarium) were evaluated between 2013 and 2015. Additionally, sixteen cultivars and accessions of $M$. sativa were evaluated in raised beds, with nine from Australia, two from Spain, two from California and three of Andean origin. We evaluated plant survival, nodulation, plant height at the end of the winter period and temporal distribution of biomass production. The persistence of $M$. sativa cultivars was high (over $80 \%$ survival after three years), but only the lucerne produced high yields (8-11 Mg ha ${ }^{-1}$ in the third season). Significant differences for winter production were detected among the lucerne cultivars, associated with their winter activity class, but no differences were found in total biomass production. The persistence of $L$. tenuis, L. corniculatus and $H$. coronarium was poor, and the biomass production was low, most likely because rhizobia failed to persist. Based on these preliminary results on perennial legumes, lucerne has great potential as a forage crop in the interior drylands of central Chile. However, more research on rhizobial strains, nodulation, plant growth and biomass accumulation, and root distribution and water use, among other factors, is required to better understand the persistence of perennial legumes in rain fed environments.
\end{abstract}

Key words: Dryland lucerne, perennial legumes, Mediterranean pastures.

Received March 12, 2015. Accepted July 3, 2015.

Corresponding author: adelpozo@utalca.cl 


\section{Introduction}

In climates with rainfall predominantly in the winter and long, dry summers, such as in central Chile, the introduction of annual legumes and grasses has been the primary strategy during the last twenty years to improve the productivity of livestock farming systems and to contribute to the rehabilitation of degraded agroecosystems. The soils of most dryland farming systems are highly degraded because of erosion and nutrient depletion and low water infiltration and holding capacity, which consequently lead to low productivity and sustainability (Martinez et al., 2011). To improve these degraded soils, the collection and domestication of naturalized annual legumes in Chile (i.e., Medicago polymorpha) and the introduction of several accessions and cultivars (cvs.) of annual legumes of the genera Trifolium, Medicago, Ornithopus and Biserrula from Western Australia were evaluated in previous studies. The productivity and persistence of $B$. pelecinus, $O$. compressus and $T$. michelianum are clearly superior to those of other annual legumes (i.e., M. polymorpha or T. subterraneum) sown in areas with degraded soils (del Pozo and Ovalle, 2009; Ovalle et al., 2005; 2006; 2010). Unfortunately, the growth rate of annual legumes is low during autumn and winter, and plant senescence typically begins by the middle of spring because of low soil water availability. As a consequence, biomass production is primarily concentrated in the spring when temperatures are moderate and soil water is available. In other Mediterranean climates, particularly in southern Australia, the use of perennial legumes is a research priority to improve the temporal distribution of forage production and tackle environmental problems such as salinization and erosion (Cocks, 2001). In these areas, perennial legumes are resilient and are compatible with crop and livestock systems under low and medium rainfall (400 to $700 \mathrm{~mm}$ annual rainfall) (Dear et al., 2003; Ward, 2006). The primary perennial species are Medicago sativa, Lotus tenuis, L. corniculatus, and Hedysarum coronarium.
Medicago sativa (lucerne) is one of the most drought tolerant perennial legumes (Li et al., 2008) and can survive long dry periods because of its deep root system (Ward et al., 2001). When the availability of soil water is low or absent in summer, lucerne is dormant, and when the rains begin in early autumn, growth restarts (Humphries and Auricht, 2001). In dryland Mediterranean environments, high yields are achieved (Latta et al., 2002; Dear et al., 2003) and large amounts of nitrogen are fixed with lucerne (Peoples et al., 1998). Additionally, when incorporated into cropping rotations, lucerne improves soil structure and increases the yield of the following crop (Latta et al., 2001; Dear et al., 2003). Nevertheless, lucerne is poorly adapted to winter waterlogging (Hill, 1996), is sensitive to acidic soils and aluminum (Munns, 1965), and cannot tolerate continuous grazing (McKinney, 1974). The dryland cultivars of lucerne are selected based on survival during establishment, grazing tolerance (Humphries et al., 2006), general adaptation (Bouton, 2012) and persistence through drought conditions (Marshall et al., 2008). A key trait for the tolerance to water stress is the development of a large taproot in lucerne (Johnson and Tieszen, 1994). In deep sandy soils, water is extracted from depths of at least $5 \mathrm{~m}$ by the roots of lucerne (Fillery and Poulter, 2006). During summer, the taproot accesses water available in the deeper soil layers, and in the fall and spring, by contrast, the shallow roots absorb most of the water and nutrients (Meyers et al., 1996). In addition to rooting depth, small crowns, leaf pubescence, thick cuticle and reduced leaf area improve the drought tolerance of lucerne (Humphries and Auricht, 2001).

Hedysarum coronarium, common name sulla, is a biannual legume species from the western Mediterranean and north Africa, with a distribution from sea level to the frost line in the uplands (Marghali et al., 2005). The yields of sulla are high in neutral to slightly acidic soils with light to medium texture (Dear et al., 2003). Sulla is a semi-erect to erect plant that is 0.3 to $1.5 \mathrm{~m}$ in height, with a deep taproot over $2 \mathrm{~m}$ in length 
and numerous secondary roots. Because of the high palatability and nutritional value, sulla has become a valuable forage plant in semiarid Mediterranean countries such as Greece, Italy, Spain and Portugal (Marghali et al., 2005). However, sulla is widespread only in Italy, which has 250,000 ha sown to several commercial varieties of this species (Le Houérou, 2002).

The genus Lotus contains approximately 100 annual and perennial species distributed worldwide, with the primary center of diversity in the Mediterranean region, including the Canary Islands (Escaray et al., 2012). Several species of Lotus are economically important, including L. corniculatus L., L. uliginosus Schkuhr, L. sub-biflorus Lagasca and L. tenuis Waldst et Kit. (narrow-leaf trefoil) (Escaray et al., 2012). Lotus tenuis is an important forage species in the Americas, particularly in the temperate or sub-temperate areas of Argentina, Chile, Uruguay and the USA, with 160,000 ha (Escaray et al., 2012). The species is tolerant to waterlogging and salinity and also recovers well after prolonged dry periods (Clua et al., 2009; Escaray et al., 2012). In an evaluation of twelve accessions of L. tenuis naturalized in Chile, genotypic variability for drought tolerance was demonstrated under different water regimes in glasshouse conditions (Acuña et al., 2010). With L. tenuis, the pasture productivity of irrigated vertisols was 6.3 and $9.3 \mathrm{Mg} \mathrm{ha}^{-1}$ in the first and second years, respectively (Acuña, 1998).

In this paper, we present the first results from a new line of research focused on the introduction and assessment of perennial legumes with deep rooting systems to extend the production period and increase pasture productivity. The objectives of the study were to introduce perennial forage legumes and evaluate the productivity and the persistence to summer drought in the rain fed Mediterranean environments of central Chile.

\section{Materials and methods}

\section{Description of sites and field experiments}

Two field experiments were conducted at the experimental center of Cauquenes-INIA ( $35^{\circ} 58^{\prime} \mathrm{S}, 72^{\circ} 17^{\prime}$ $\mathrm{W} ; 140$ m.a.s.1.), which is located in the eastern part of the coastal mountain range (interior dryland) in the sub-humid Mediterranean zone of Chile. The soil is a granitic classified as ultic palexeralf. The soil $\mathrm{pH}(1: 5$ in water, $0-20 \mathrm{~cm})$ was 7.0 , the organic matter content was $1.6 \%$ and the concentrations of available mineral $\mathrm{N}, \mathrm{P}$ and $\mathrm{K}$ in the top $20 \mathrm{~cm}$ were $2.3 \mathrm{mg} \mathrm{kg}^{-1}, 12 \mathrm{mg} \mathrm{kg}^{-1}$ and $185 \mathrm{mg} \mathrm{kg}^{-1}$, respectively, based on the methodologies in Sadzawka et al. (2006). The average annual temperature is $14.7^{\circ} \mathrm{C}$, with the minimum average of $4.7^{\circ} \mathrm{C}$ (July) and the maximum average of $27^{\circ} \mathrm{C}$ (January). The long-term average annual precipitation is $695 \mathrm{~mm}$, with a six-month (November to April) dry season (del Pozo and del Canto, 1999). The annual rainfall was exceptionally low compared with the long-term average of $650 \mathrm{~mm}$ in 2012 and 2013 at the site of the experiments (Table 1). In 2014, the annual rainfall increased but was $70 \mathrm{~mm}$ less than the 30-year average. In 2012, approximately $50 \%$ of the total annual rainfall occurred in the spring, which is an unusual phenomenon in the Mediterranean zone of Chile. In 2013 and 2014, approximately 80\% of the rainfall was concentrated in winter, which approximated the normal distribution of rainfall in this zone. The temperatures in 2012 were higher than those in the other two years of the experiment. A water deficit occurred from September to April, when evapotranspiration was higher than precipitation (Table 1).

Both experiments were under naturalized pasture before the start of the study. The soil was prepared using a chisel plow and disc harrows one month before sowing. In a randomized complete block design with four replicates, two-month-old 
Table 1. Mean monthly and annual temperatures $\left({ }^{\circ} \mathrm{C}\right)$, rainfall and evapotranspiration $(\mathrm{mm})$ of the experimental site.

\begin{tabular}{|c|c|c|c|c|c|c|c|c|c|c|c|c|c|}
\hline & Jan & $\mathrm{Feb}$ & Mar & Apr & May & Jun & Jul & Aug & Sep & Oct & Nov & Dec & Annual \\
\hline \multicolumn{14}{|l|}{$\mathrm{T}\left({ }^{\circ} \mathrm{C}\right)$} \\
\hline 2012 & 21.0 & 21.5 & 21.9 & 14.2 & 11.3 & 9.2 & 11.9 & 11.5 & 15.4 & 12.8 & 16.8 & 17.0 & 15.4 \\
\hline 2013 & 21.2 & 20.3 & 17.7 & 14.2 & 10.8 & 8.7 & 8.1 & 8.3 & 10.0 & 13.2 & 16.1 & 20.5 & 14.1 \\
\hline 2014 & 21.3 & 19.3 & 17.2 & 13.0 & 11.1 & 8.0 & 6.2 & 10.0 & 11.9 & 14.2 & 16.2 & 18.8 & 13.9 \\
\hline 30 years & 20.3 & 18.0 & 15.0 & 12.0 & 9.5 & 9.2 & 9.7 & 11.4 & 13.4 & 16.6 & 19.4 & 20.3 & 14.5 \\
\hline \multicolumn{14}{|l|}{$\mathrm{PP}(\mathrm{mm})$} \\
\hline 2012 & 5 & 34 & 0 & 13 & 10 & 9 & 14 & 23 & 3 & 25 & 70 & 30 & 236 \\
\hline 2013 & 0 & 11 & 1 & 1 & 136 & 86 & 79 & 36 & 19 & 29 & 1 & 0 & 397 \\
\hline 2014 & 0 & 5 & 11 & 15 & 133 & 200 & 29 & 152 & 3 & 13 & 0 & 9 & 570 \\
\hline 30 years & & & & & & & & & & & & & 649 \\
\hline \multicolumn{14}{|c|}{ Evapotranspiration (mm) } \\
\hline 2012 & 71 & 61 & - & - & - & - & - & - & - & 73 & 125 & 129 & 458 \\
\hline 2013 & 151 & 116 & 91 & 49 & 24 & 14 & 17 & 32 & 54 & 92 & 126 & 157 & 922 \\
\hline 2014 & 149 & 115 & 88 & 47 & 22 & 8 & 5 & 31 & 11 & 99 & 124 & 140 & 828 \\
\hline
\end{tabular}

seedlings of each genotype were planted in two $3 \mathrm{~m}$ long rows separated by $40 \mathrm{~cm}(60$ plants per plot). In experiment 1 , sixteen genotypes from four perennial legume species were established in May 2012: nine cultivars of M. sativa, two of H. coronarium, three of Lotus tenuis and two of Lotus corniculatus (Table 2). In experiment 2, eight additional genotypes from two perennial legume species were established in May 2013: seven cvs. of $M$. sativa and one $H$. coronarium were examined (Table 3). Both experiments were completed in December 2014.

In experiment 1 , the seedlings were inoculated with the appropriate strain of root nodule bacteria suspended in $1 \%(\mathrm{~W} / \mathrm{V})$ sucrose at a concentration of $10^{6} \mathrm{CFU}$ per plant and grown under glasshouse conditions. The M. sativa cultivars were inoculated with strain WSM2141, Lotus spp. with WSM166 and H. coronarium with WSM1592. The rhizobial strains were obtained from the Western Australia Soil Microbiology (WSM) culture collection at the Center for Rhizobium Studies, Murdoch University, Australia. In experiment 2, the seeds of $M$. sativa were lime-pelleted with the inoculant before sowing. To assess nodulation effectiveness in experiment 1 , three plants per plot were sampled at two months and at one year after sowing. The rhizobia were re-isolated and the identities confirmed through RAPD-PCR fingerprinting using the primer RPO1 (Richardson et al., 1995). Fertilizer-free nitrogen was applied at seedling establishment, with $90 \mathrm{~kg} \mathrm{P}_{2} \mathrm{O}_{5} \mathrm{ha}^{-1}$, $2000 \mathrm{~kg} \mathrm{CaCO}_{3} \mathrm{ha}^{-1}, 100 \mathrm{~kg} \mathrm{~K}_{2} \mathrm{SO}_{4} \mathrm{ha}^{-1}$ and $20 \mathrm{~kg}$ boron calcite ha-1.

\section{Evaluation of survival, growth and biomass}

To assess plant establishment (\%), live plants in one of the $3 \mathrm{~m}$ rows per plot were counted at the start of the second growing season (autumn). The plant height $(\mathrm{cm})$ was measured at the end of the second winter (August) to determine growth and the class of winter dormancy, with dormancy classes that ranged from 3 to 10: dormant $(3,4)$; semi-dormant (5); winter-active $(6,7)$; and highly winter-active $(8,9,10)$. The plant biomass was determined by cutting the entire plot to $5 \mathrm{~cm}$ at the end of the growing season (December) in the first year of the experiments and in September, November and January in the second and third years. For dry matter (DM) determination, the plant samples were oven-dried with forced-air ventilation at 70 ${ }^{\circ} \mathrm{C}$ until a constant weight was reached. 


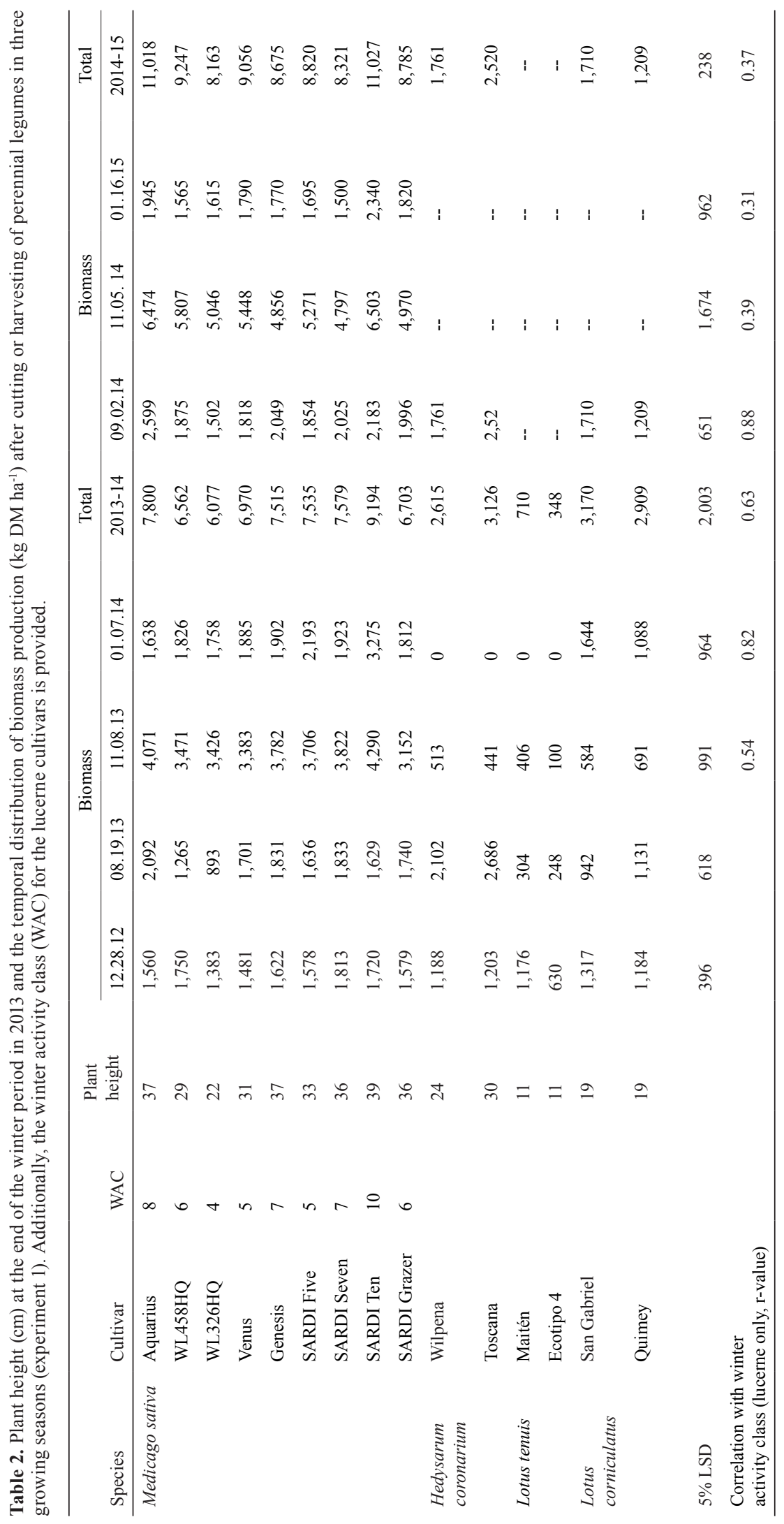


Table 3. Plant height $(\mathrm{cm})$ at the end of the winter period in 2014 and biomass production $\left(\mathrm{kg}\right.$ DM ha $\left.{ }^{-1}\right)$ of perennial legumes in two seasons (experiment 2).

\begin{tabular}{lllllll}
\hline \multirow{2}{*}{ Species } & & & \multicolumn{3}{c}{ Biomass } \\
\cline { 5 - 7 } & Cultivar & Plant height & $18 / 12 / 13$ & $26 / 08 / 14$ & $05 / 11 / 14$ & Total 2014 \\
\cline { 5 - 7 } & Alta Sierra & 54.3 & 1,256 & 3,586 & 5,317 & 8,903 \\
& Aragon 1 & 49.0 & 1,158 & 2,423 & 4,536 & 6,959 \\
\cline { 5 - 6 } Medicago sativa & Alcoroches & 35.0 & 1,148 & 2,459 & 4,418 & 6,877 \\
& Aragon 2 & 48.5 & 1,228 & 2,584 & 4,948 & 7,532 \\
& Mediterránea & 57.3 & 1,240 & 3,077 & 4,402 & 7,480 \\
\multirow{2}{*}{$\begin{array}{l}\text { Hedysarum } \\
\text { coronarium }\end{array}$} & WL903 & 55.8 & 1,807 & 4,057 & 6,478 & 10,536 \\
5\% LSD & Alta Sierra & 54.5 & 1,056 & 3,848 & 5,051 & 8,899 \\
\hline
\end{tabular}

\section{Phenological studies of lucerne cultivars}

Sixteen cultivars and accessions of lucerne, with nine from Australia, two from Spain, two from California and three of Andean origin, were evaluated on raised beds at the experimental center of Cauquenes-INIA in 2013 (Experiment 3; Table 4). The seeds were pregerminated in petri dishes at $20^{\circ} \mathrm{C}$ and were inoculated with rhizobia strain WSM2141 with the lime pelleting of seeds. A mixture of $\mathrm{P}_{2} \mathrm{O}_{5}\left(35 \mathrm{~g} \mathrm{~m}^{-2}\right)$ and $\mathrm{K}_{2} \mathrm{O}\left(17.5 \mathrm{~g} \mathrm{~m}^{-2}\right)$ fertilizer was applied. Each variety was planted in a single $1.1 \mathrm{~m}$ row with $20 \mathrm{~cm}$ spacing between the plants on July 15, 2013. The raised beds were filled with $1.5 \mathrm{~m}$ of granitic soil.

Twenty individual plants were evaluated twice each week to distinguish four phenophases: foliation (days from emergence to appearance of the first true leaf), flowering (days from emergence to appearance of the first flower), fructification (days from the first flower to the first fruit) and summer dormancy (approximately 50\% of the plants are dormant). Additionally, plant height was determined at the end of winter (August) and biomass production in August and December.

The results were evaluated with analysis of variance (ANOVA). When differences were statistically significant, a least significant difference (LSD) comparison was used to separate means with a confidence level of $95 \%(\mathrm{P}<0.05)$. All statistical analyses were conducted with the SAS statistical software package (SAS Institute Inc., Cary, North Carolina, USA, 1999) for Windows V8.

\section{Results}

\section{Plant survival and winter growth}

In experiment 1 , the survival of plants was very low ( $<16 \%)$ for L. tenuis, L. corniculatus and $H$. coronarium three years after establishment (Figure 1). The nine cultivars of $M$. sativa all had survival rates greater than $80 \%$, with approximately $90 \%$ survival of the SARDI Grazer, Venus and SARDI Ten cultivars (Figure 1). In experiment 2 , the survival rates of $H$. coronarium were below $40 \%$, whereas for all the accessions of $M$. sativa, the survival exceeded $85 \%$ (Figure 2). The few surviving plants of $L$. tenuis and $L$. corniculatus accessions in experiment 1 also had low winter growth. Hedysarum coronarium $\mathrm{cv}$. Toscana had higher growth than that of $\mathrm{cv}$. Wilpena (Table 2). The nine cultivars of $M$. sativa differed significantly in plant height in the winter period; the tallest cultivars were SARDI Ten, Aquarius and Genesis, whereas the cultivars with the lowest winter growth were WL326HQ, 
Table 4. Plant height, total and winter biomass production and winter activity class of 16 cultivars of lucerne in raised beds in 2014 (experiment 3).

\begin{tabular}{|c|c|c|c|c|}
\hline Cultivar & $\begin{array}{c}\text { Winter Activity } \\
\text { Class }\end{array}$ & $\begin{array}{l}\text { Plant Height } \\
(\mathrm{cm})\end{array}$ & $\begin{array}{l}\text { Winter Biomass } \\
\quad\left(\mathrm{kg} \mathrm{ha}^{-1}\right)\end{array}$ & $\begin{array}{c}\text { Total } \\
\text { Biomass } \\
\left(\mathrm{kg} \mathrm{ha}^{-1}\right)\end{array}$ \\
\hline Aquarius & 8 & 55.3 & 2,812 & 8,988 \\
\hline WL458HQ & 6 & 52.3 & 3,612 & 11,161 \\
\hline WL326HQ & 4 & 39.0 & 2,302 & 11,709 \\
\hline Venus & 5 & 46.3 & 2,419 & 12,135 \\
\hline Genesis & 7 & 60.4 & 5,015 & 16,153 \\
\hline SARDI Five & 5 & 44.3 & 2,312 & 9,197 \\
\hline SARDI Seven & 7 & 52.7 & 3,603 & 12,247 \\
\hline SARDI Ten & 10 & 55.0 & 3,965 & 12,303 \\
\hline SARDI Grazer & 6 & 50.0 & 2,726 & 10,267 \\
\hline Alta Sierra & & 67.5 & 4,317 & 9,378 \\
\hline Aragon 1 & & 50.9 & 2,048 & 5,981 \\
\hline Alcoroches & & 44.3 & 1,778 & 6,485 \\
\hline Mediterránea & & 67.5 & 4,142 & 10,333 \\
\hline WL903 & 9 & 52.8 & 3,190 & 10,721 \\
\hline Alta Sierra Illapata 1 & & 70.1 & 3,982 & 10,062 \\
\hline Alta Sierra Illapata 2 & & 64.5 & 3,790 & 9,285 \\
\hline $5 \% \mathrm{LSD}$ & & 12.1 & 1,172 & 3,18 \\
\hline
\end{tabular}

WL426HQ and Venus (Table 2). The accession of $H$. coronarium in experiment 2 had much lower winter growth than that of the cultivars of $M$. sativa (Table 3), and the differences in growth among $M$. sativa cultivars were small. In the raised bed experiment (experiment 3), differences in winter growth were more evident among cultivars of $M$. sativa (Table 4). The tallest cultivars were Genesis, Alta Sierra, Alta Sierra Ispallata 1 and 2, and Mediterránea, with height that ranged between 60.4 and $70.1 \mathrm{~cm}$; whereas lower growth was observed for the cultivars WL326HQ, SARDI Five and Alcoroches.

In experiment 1 , all plants of $M$. sativa were nodulated two months after inoculation, with nodule numbers that ranged from 10 to 20. Determined with RPO1-PCR fingerprinting, the average nodule occupancy of strain WSM2141 was 74\%. A year after sowing, the nodule numbers of lucerne were between 46 and 58; however, the nodule occupancy of the inoculant strain (WSM2141) was reduced to $36 \%$. For Lotus spp., the nodule occupancy of the inoculant strain (WSM166) at the one year stage was $58 \%$. One year after sowing, although the average nodule number of Lotus spp. increased to 30-40 per plant, none of the recovered rhizobia strains corresponded to strain WSM166. For $H$. coronarium, no nodules

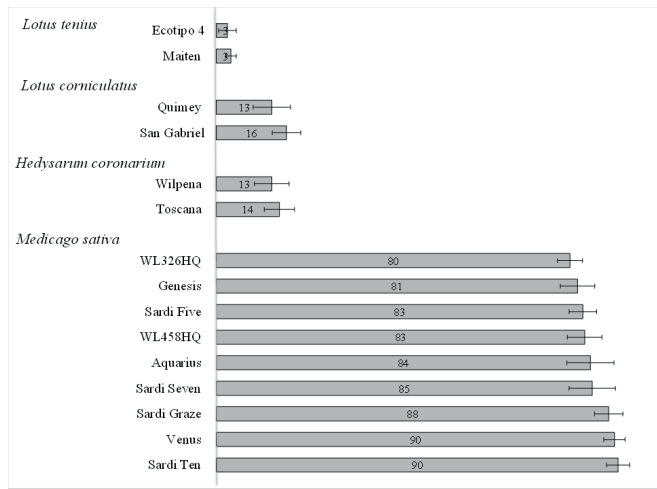

Figure 1. Plant survival (\%) of perennial legumes three years after establishment in experiment 1 . The density at establishment was 60 seedlings per plot $\left(25\right.$ plants $\left.\mathrm{m}^{-2}\right)$. $\mathrm{LSD}=8.8$. The values indicate the percentages. 


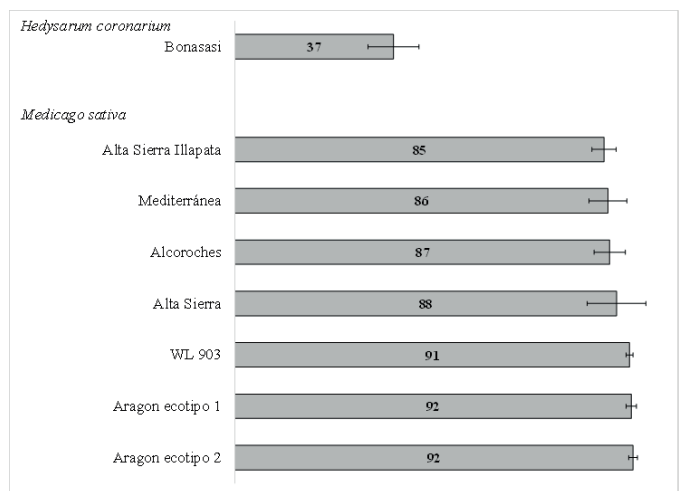

Figure 2. Plant survival (\%) of perennial legumes two years after establishment in experiment 2 . The density at establishment was 60 seedlings per plot $\left(25\right.$ plants $\left.\mathrm{m}^{-2}\right)$. $\mathrm{LSD}=8.6$. The values indicate the percentages.

were recorded two months after seedling inoculation; however, a year after sowing, the surviving plants were abundantly nodulated. Nevertheless, when re-isolated, the bacteria did not match the fingerprinting patterns of the original inoculant (WSM 1592) and therefore were native or naturalized soil bacteria.

The seasonal production of biomass and the phenology of lucerne

In experiment 1 in the first season (2012), the plots were cut only once at the end of the growing period, and two groups of perennial legumes differed significantly in yield. The highest production (between 1,383 and 1,813 $\mathrm{kg} \mathrm{DM} \mathrm{ha}^{-1}$ ) was obtained with lucerne in the first group, with no differences detected among the cultivars. For the second group, the production was lower (between 630 and 1,317 $\mathrm{kg} \mathrm{DM} \mathrm{ha}^{-1}$ ) for the accessions of $L$. corniculatus, L. tenuis and H. coronarium (Table 2). In the second and third years of evaluation (2013 and 2014), the plots were cut three times (September, October and January). The production of lucerne was much higher in the second and third years than that in the first season, and ranged from 8,000 to $11,000 \mathrm{~kg} \mathrm{DM} \mathrm{ha}^{-1}$ in the third year. The top producing lucerne cultivars were SARDI Ten and Aquarius with production of $11,000 \mathrm{~kg} \mathrm{DM} \mathrm{ha}^{-1}$. For the other three species of perennial legumes, the yields were very low (Table 2). In experiment 2 in 2013 in the first season of assessment, the plots were cut once at the end of the growing season (December); the lucerne cultivars produced significantly more biomass than that of H. coronarium (Table 3). In 2014, the total production (with three cuts in the season) of lucerne cultivars greatly exceeded that in 2013; additionally, the biomass of $H$. coronarium was very low. The most productive lucerne cultivar was WL903, followed by Alta Sierra and Alta Sierra Illapata.

In 2013 (experiment 1), the production of the Australian-origin cultivars did not differ statistically in winter (August evaluation), with production that ranged from 1,629 to $2,092 \mathrm{~kg}$ $\mathrm{DM} \mathrm{ha}^{-1}$ (Table 2), but the winter growth of the Californian cvs. WL326HQ and WL456HQ was lower than that of the Australian cvs. However, in the third year (September 2, 2014), no significant differences were detected among lucerne cultivars (Table 2). In experiment 2 , the higher production of lucerne cultivars than that of H. coronarium was verified, with the most productive cultivars during the winter period WL903, Alta Sierra and Alta Sierra Illapata (Table 3). In the raised beds, the winter production was significantly different among the cultivars (Table 4), and the most productive cultivars were SARDI Ten, Alta Sierra Illapata, Mediterránea, Alta Sierra and Génesis, with values ranging from 3970 to 5020 $\mathrm{kg} \mathrm{DM} \mathrm{ha}{ }^{-1}$. The less productive cultivars were Alcoroches, Aragón, WL326HQ, SARDI Five and Venus (Table 4).

The summer production of SARDI Ten was significantly higher (3,275 $\mathrm{kg} \mathrm{DM} \mathrm{ha}^{-1}$; Table 3) than that of the other lucerne cultivars in experiment 1, with no significant differences among the other cultivars. The Lotus corniculatus cultivars San Gabriel and Quimey produced between 1,088 and 1,644 kg DM ha-1 (Table 3). In experiment 2, no differences in summer production between the lucerne cultivars were found, with production that ranged from 1,565 to $2,340 \mathrm{~kg} \mathrm{DM} \mathrm{ha}{ }^{-1}$. The 
other genotypes did not produce in the summer (Table 3).

For the lucerne cultivars, the time from plant emergence to appearance of the first trifoliate leaf ranged from 42 to 51 days, and the flowering time ranged from 153 to 161 days. The first fruit appeared between 173 and 176 days after plant emergence.

\section{Discussion}

The study area received very low rainfall in two of the three experimental years (2012 and 2013), and therefore, the evaluation of perennial legumes was conducted under the most extreme conditions expected. For $M$. sativa, plant survival was high in these dry conditions (over $80 \%$ survival; Figure 1). The production of lucerne cvs. SARDI Ten and Aquarius averaged $8.4 \mathrm{tha}^{-1}$ in 2013 and $11 \mathrm{t} \mathrm{ha}^{-1}$ in 2014, years that received 397 and 570 $\mathrm{mm}$ of annual rainfall, respectively $(61 \%$ and $87 \%$ of the long-term average annual rainfall, respectively). The apparent water use efficiency of lucerne in this study (19-21 kg DM ha $\mathrm{mm}^{-1}$ of rainfall) is much greater than that reported for similar Mediterranean climates in southern Australia (Latta et al., 2002, Ward, 2006; Humphries et al., 2008). This increases in efficiency likely caused by the greater root volume and the water holding capacity of the soil at this location. For the temporal distribution of lucerne production (Table 2), approximately half of the forage was produced in September and October when rainfall was $16 \mathrm{~mm}$ and $48 \mathrm{~mm}$ in 2013 and 2014, respectively, indicating that stored soil moisture likely contributed to plant growth. A further $20 \%$ of the forage was produced between November and January when rainfall was negligible. The out-of-season production demonstrated that lucerne could use stored soil moisture that is not accessible to annual pasture species or it is assumed, to the other, more shallow-rooted perennial legumes evaluated in this study. Compared with lucerne, the production of winter biomass was proportionally higher in Lotus, with approximately $30 \%$ of the total in 2013 and $100 \%$ of the production in 2014. For H. coronarium, $84 \%$ of the production occurred in the winter; however, this high proportion of production reflected the high level of summer dormancy, which is used as a drought tolerance mechanism for this species. Hedysarum coronarium is drought tolerant in the native environments of the Mediterranean islands and in Australia but was not persistent in this study. The poor persistence of this species might be related to the absence of nodulation that was observed in the first year. Similarly, the low persistence of L. tenuis and L. corniculatus could be caused by failures in the persistence of rhizobia and therefore in the low effectiveness of nodulation.

A key factor to successfully introduce a legume into a new environment is the inclusion of an effective symbiotic partner (Lindström et al., 2010; Gerding et al., 2013). The strains used for the inoculation of M. sativa, Lotus spp. and $H$. coronarium were selected as effective strains for these species, with some strains used as commercial inoculants in Australia (Langer et al., 2008; de Koning et al., 2010; Howieson et al., 2011). In this study, strain WSM2141 was found in most of the nodules from $M$. sativa two months after sowing and in $32 \%$ of the nodules a year later; however, in L. corniculatus, L. tenuis and H. coronarium, the inoculant strains were completely displaced by soil rhizobia. This difference in effectiveness of inoculation could explain, in part, the high performance of M. sativa compared with the other legumes. Therefore, the study and selection of naturalized or native soil rhizobia that effectively nodulate Lotus spp. and $H$. coronarium and that are adapted to the Chilean Mediterranean conditions are essential for future field studies.

The growth of plants during the winter period differed among species and cultivars, with the difference between the growth of Lotus spp. and that of $M$. sativa well known. The differences in growth observed among the lucerne cultivars were 
correlated with the degree of winter dormancy. For example, the Californian cvs. WL326HQ and WL426HQ had dormancy ratings of 4 and 6 , respectively, and both had low winter growth, particularly the cv. WL326HQ (Tables 3 and 5). Similarly, the cvs. Aragón and Alcoroches, with high degrees of winter dormancy (low dormancy rates), had the lowest growth in the winter. The winter growth observed in experiment 3 (Table 4) was clearly reflected in the dormancy rates of the Australian cultivars: 5 (SARDI Five and Venus), 6 (SARDI Grazer), 7 (SARDI Seven and Genesis), 8 (Aquarius) and 10 (SARDI Ten) (Humphries et al 2004; Moore et al., 2006). However, the differences in the field experiment were not as clear (Table 2). In the raised bed experiment, as an indication of low winter dormancy in the genotypes, the cvs. Genesis and Mediterranea and the three accessions of Alta Sierra also had high winter growth.

Among the lucerne cultivars, the differences detected in total biomass production were not large; a large group of cultivars exceeded $8,000 \mathrm{~kg} \mathrm{DM} \mathrm{ha}^{-1}$ that included Genesis, SARDI Ten, SARDI Seven, WL903, Venus, Aquarius and the three genotypes of Alta Sierra. These levels of biomass production are greater than those obtained in drylands in South Australia by Humphries et al. (2008). The high production of the accessions of the ancestral Alta Sierra lucerne is particularly relevant because this germplasm originates from the Illapata Valley in northern Chile. The Spanish settlers introduced lucerne into the valleys of the Atacama Desert, with the first reports of cultivation in 1713 (Hidalgo, 2004). The adaptation of the Alta Sierra provides a notable case study on the natural selection of lucerne over the past three centuries to different grazing systems and cutting across a range of environments. Thus, the Alta Sierra cultivars are an immensely valuable and unique resource for plant breeders because these cultivars are the product of 20-60 generations of farmer-based selection for tolerance to drought, salt and grazing.

Compared with the annual legumes currently used in the Mediterranean zone of Chile, the growth dynamics with the seasonal distribution of production is one of the most relevant aspects of incorporating perennial legumes into livestock farming systems (Humphries et al., 2008). The production obtained at the end of winter is a resource of high value because for annual pastures, this is a period of essentially no production. The high production in spring is another resource of high value for conserving forage and haymaking. Furthermore, the production in late spring/early summer is a resource that can extend the grazing period for approximately two months. The typical production of annual legume pastures does not exceed 4,000 $\mathrm{kg} \mathrm{DM} \mathrm{ha}^{-1}$ because of the short period in which water is available at the soil surface (Ovalle et al., 2005; Espinoza et al, 2011), with senescence occurring in late October/early November. In contrast to the annual pastures, lucerne uses the available water in deeper soil profiles and remains active and growing until the first half of January. In the study of the phenology of lucerne cultivars in raised beds, the genotypes all reached foliation, flowering and fruiting in similar periods of time.

In conclusion, several cultivars of lucerne had high rates of survival when the plants were established under conditions of severe summer water stress that prevailed in the interior drylands of the Mediterranean subhumid zone of Chile. By contrast, the genotypes of the genera Lotus and Hedysarum did not persist in this environment. Among the lucerne cultivars, the differences in total production were not large, and a large group of cultivars exceeded $8,000 \mathrm{~kg} \mathrm{DM} \mathrm{ha}^{-1}$. The cultivars Genesis, SARDI Ten, SARDI Seven, WL903, Venus, and Aquarius and the three Andean Alta Sierra accessions were among the most productive. The cultivars with low or no winter dormancy were most productive and therefore the most appropriate for the rain fed Mediterranean conditions of Chile. Moreover, with the low winter dormancy lucerne cultivars, the distribution of seasonal forage production increased. Indeed, the most productive cultivars produced 2,000 kg DM $\mathrm{ha}^{-1}$ in late winter, compared with zero by any 
of the annual legume options currently used in production systems. Furthermore, the production in late spring-early summer can prolong animal grazing for approximately two months, compared with grazing with annual legumes. Thus, based on these first, preliminary results for perennial legumes, the potential of lucerne as a forage crop in the interior drylands of central Chile is high. However, more research on rhizobial strains, nodulation, plant growth and biomass accumulation, and root distribution and water use, among other factors, is required to better understand the persistence of perennial legumes in these rain fed environments.

\section{Acknowledgements}

This study was conducted thanks to the financial support of the Fondo Nacional de Desarrollo Científico and Tecnológico, Project FONDECYT No. 1128829, Chile.

\section{Resumen}

C. Ovalle, S. Espinoza, V. Barahona, M. Gerding, A. Humphries, y A. del Pozo. 2015. Alfalfa y otras leguminosas perennes ofrecen nuevas opciones para la producción ganadera de secano en la región de clima mediterráneo de Chile. Cien. Inv. Agr. 42 (3): 461-474. En ambientes mediterráneos de secano, la productividad de leguminosas anuales es baja durante el otoño y el invierno, y la senescencia típicamente comienza a mediados de la primavera debido a la baja disponibilidad de agua en el suelo. Por lo tanto, el uso de leguminosas perennes con raíces pivotantes profundas puede proporcionar una alternativa a las leguminosas anuales en las regiones con un déficit de humedad del suelo. Se evaluó el germoplasma de nuevas leguminosas perennes con sistemas de raíces profundas en dos experimentos de campo en el secano interior de Chile central. En el experimento 1, se evaluaron dieciséis genotipos de cuatro especies de leguminosas perennes, nueve cultivares (cvs.) de Medicago sativa, dos de Hedysarum coronarium, tres de Lotus tenuis y dos de Lotus corniculatus, durante tres temporadas (20122014). En el experimento 2, se evaluaron ocho genotipos adicionales de dos especies de leguminosas perennes (M. sativa y H. coronarium) entre 2013 y 2015. Además, se evaluaron dieciséis cultivares y accesiones de $M$. sativa en bancadas, nueve de Australia, dos de España, dos de California y tres de origen andino. Se evaluó la supervivencia de la planta, la nodulación, altura de la planta al final del período de invierno y distribución temporal de la producción de biomasa. La persistencia de cultivares de $M$. sativa fue alta (más del $80 \%$ de supervivencia a los tres años), pero sólo la alfalfa produjo altos rendimientos (8-11 $\mathrm{Mg} \mathrm{ha}^{-1}$ en la tercera temporada). Se detectaron diferencias significativas para la producción de invierno entre los cultivares de alfalfa, lo que estuvo asociado a la clase de actividad de invierno, pero no se encontraron diferencias en la producción total de biomasa. La persistencia de L. tenuis, L. corniculatus y $H$. coronarium fue pobre y la producción de biomasa fue baja, muy probablemente porque los rizobios no pudieron persistir. Sobre la base de estos resultados preliminares obtenidos en leguminosas perennes, la alfalfa tiene un gran potencial como cultivo forrajero en el secano interior Chile central. Sin embargo, se requiere de más investigación acerca de las cepas de rizobios, nodulación, crecimiento y acumulación de biomasa, la distribución de la raíz y el uso del agua, entre otros factores, para entender mejor la persistencia de las leguminosas perennes en ambientes de secano.

Palabras clave: alfalfa de secano, legumbres perennes, praderas Mediterráneas. 


\section{References}

Acuña, H. 1998. Comparación de variedades de tres especies del género Lotus (L. corniculatus L., L. uliginosus Cav. y L. tenuis Wald et Kit). Agricultura Técnica 58:7-14.

Acuña, H., L. Inostroza, M.P. Sánchez, and G. Tapia. 2010. Drought-tolerant naturalized populations of Lotus tenuis for constrained environments. Acta Agriculturae Scandinavica, Section B Soil and Plant Science 60:174-181.

Bouton, J.H. 2012. Breeding lucerne for persistence. Crop and Pasture Science 63:95-106.

Clua A., M. Paez, H. Orsini and J. Beltrano. 2009. Incidence of drought stress and rewatering on Lotus tenuis. Effects on cell membrane stability. Lotus Newsletter 39:21-27.

Cocks, P.S. 2001. Ecology of herbaceous perennial legumes: a review of characteristics that may provide management options for the control of salinity and waterlogging in dryland cropping systems. Australian Journal of Agricultural Research 52:137-151.

Dear, B.S., G.A. Moore, and S.J. Hughes. 2003. Adaptation and potential contribution of temperate perennial legumes to the southern Australian wheat belt: a review. Australian Journal of Experimental Agriculture 43:1-18.

de Koning, C., T. Yates, and M. Wurst. 2010. Sulla (Hedysarum coronarium) Management package. Pastures Australia Available online at: http://www.sardi.sa.gov.au/__data/assets/pdf file/0019/136441/sardi_sulla_booklet_v5.pdf (Website accessed: March 2015).

del Pozo, A., and P. del Canto. 1999. Áreas agroclimáticas y sistemas productivos en la VII y VIII regiones. Instituto de Investigaciones Agropecuarias, Chillán, Chile. Serie Quilamapu No 113. $115 \mathrm{pp}$.

del Pozo, A. and C. Ovalle. 2009. Productivity and persistence of serradela (Ornithopus compressus) and biserrula (Biserrula pelecinus) in the Mediterranean climate region of central Chile. Chilean Journal of Agricultural Research 69:340-349.

Escaray, F.J., A.B. Menendez, A. Gárriz, F.L. Pieckenstain, M.J. Estrella, L.N. Castagno, P. Carras- co, J. Sanjuán, and O.A. Ruiz. 2012. Ecological and agronomic importance of the plant genus Lotus. Its application in grassland sustainability and the amelioration of constrained and contaminated soils. Plant Science 182:121-33.

Espinoza, S., C. Ovalle, A. del Pozo, E. Zagal, and S. Urquiaga. 2011. Biological fixation of $\mathrm{N}_{2}$ in mono and polyspecific legume pasture in the humid mediterranean zone of Chile. Chilean Journal of Agricultural Research 71:132-139.

Fillery, I.R.P., and R.E. Poulter. 2006. Use of longseason annual legumes and herbaceous perennials in pastures to manage deep drainage in acidic sandy soils in Western Australia. Australian Journal of Agricultural Research 57:297-308.

Gerding, M., J.G. Howieson, G.W O’Hara, D. Real, and L. Bräu. 2013. Establishment and survival of the South African legume Lessertia spp. and rhizobia in Western Australian agricultural systems Plant and Soil 370: 235-249.

Hidalgo, J.L. 2004. Historia andina de Chile. Volumen 1. Ed Universitaria, Santiago de Chile. 511 pp.

Hill, M.J. 1996. Potential adaptation zones for temperate pasture species as constrained by climate: a knowledge-based logical modelling approach. Australian Journal of Agricultural Research 47:1095-1117.

Howieson J.G., R.A. Ballard, R.J. Yates, and N. Charman. 2011. Selecting improved Lotus nodulating rhizobia to expedite the development of new forage species. Plant and Soil 348:231-243.

Humphries A.W., and G.C. Auricht. 2001. Breeding lucerne for Australia's southern dryland cropping environments. Australian Journal of Agricultural Research 52:153-169.

Humphries, A., E. Kobelt, and G. Auricht. 2004. Description of "SARDI Ten" Lucerne (Medicago sativa). Available online at: http://www.sardi. sa.gov.au/pastures/sardi_pasture_cultivars/lucerne_cultivars/sardi_ten_description (Website accessed: March 2015).

Humphries, A.W., E.T. Kobelt, W.D. Bellotti, and G.C. Auricht. 2006. Tolerance of Australian lucerne (Medicago sativa) germplasm to grazing by sheep. Australian Journal of Experimental Agriculture 46:1263-1270. 
Humphries A.W., X.G. Zhang, K.S. McDonald, R.A. Latta, and G.C. Auricht. 2008. Persistence of diverse lucerne (Medicago sativa spp.) germplasm under farmer management across a range of soil types in southern Australia. Australian Journal of Agricultural Research 59:139-148.

Johnson, R.C., and L.L. Tieszen. 1994. Variation for water-use efficiency in alfalfa germplasm. Crop Science 34:452-458.

Langer, H., K. Nandasena, J.G. Howieson, M. Jorquera, and F. Borie. 2008. Genetic diversity of Sinorhizobium meliloti associated with alfalfa in Chilean volcanic soils and their symbiotic effectiveness under acidic conditions. World Journal of Microbiology \& Biotechnology 24:301-308.

Latta, R.A., L.J. Blacklow, and P.S. Cocks. 2001. Comparative soil water, pasture production, and crop yields in phase farming systems with Lucerne and annual pasture in Western Australia. Australian Journal of Agricultural Research 52:295-303.

Latta, R.A., P.S. Cocks and C. Matthews. 2002. Lucerne pastures to sustain agricultural production in south-western Australia. Agricultural Water Management 53:99-109.

Le Houérou, H.N. 2002. Multipurpose germplasm of fodder shrubs and trees for the rehabilitation of arid and semi-arid land in the Mediterranean isoclimaticzone. A photographic catalogue Zaragoza: CIHEAM-IAMZ. 118 pp.

Li, G.D., G.M. Lodge, G.A. Moore, A.D. Craig, B.S. Dear, S.P. Boschma, T.O. Albertsen, S.M. Miller, S. Harden, R.C. Hayes, S.J. Hughes, R. Snowball, A.B. Smith, and B.C. Cullis. 2008. Evaluation of perennial pasture legumes and herbs to identify species with high herbage production and persistence in mixed farming zones in southern Australia. Australian Journal of Experimental Agriculture 48:449-466.

Lindström, K., M. Murwira, A. Willems, and N. Altier. 2010. The biodiversity of beneficial microbehost mutualism: The case of rhizobia. Research in Microbiology 161:453-463.

Marghali, S., O. Panaud, F. Lamy, S. Ghariani, A. Sarr, M. Marrakchi, and N. Trifi-Farah. 2005.
Exploration of intra- and inter-population genetic diversity in Hedysarum coronarium L. by AFLP markers. Genetic Resources and Crop Evolution 52:277-284.

Marshall, E.M., A.W. Humphries, E.T. Kobelt, T.D. Rowe and G.C. Auricht. 2008. Drought response of lucerne in South East and Mallee environments in SA. Available online at: http://www.sardi.sa.gov.au/_data/assets/pdf_file/0003/116553/ Persistence_Drought_response_of_Lucerne.pdf (Website accessed: March 2015)

Martinez, I., C. Ovalle, A. del Pozo, H. Uribe, N. Valderrama, C. Prat, M. Sandoval, M. Fernandez, and E. Zagal. 2011. Influence of conservation tillage and soil water content on crop yield in dryland compacted Alfisol of Central Chile. Chilean Journal of Agricultural Research 71:615-622.

McKinney, G.T. 1974. Management of lucerne for sheep grazing on the Southern Tablelands of New South Wales. Australian Journal of Experimental Agriculture and Animal Husbandry 14:726-734.

Meyers, L., M.P. Russelle, and J. Lamb. 1996. Fluridone reveals root elongation differences among alfalfa germplasms. Agronomy Journal 88:6772.

Moore, G., P. Sanford, and T. Wiley, 2006. Perennial pastures for Western Australia. Department of Agriculture and Food Western Australia, Bulletin 4690, Perth.

Munns, D.N. 1965. Soil acidity and the growth of a legume. II. Reactions of aluminium and phosphate in solution and effects of aluminium, phosphate and calcium, and $\mathrm{pH}$ on Medicago sativa L. and Trifolium subterraneum L. in solution culture. Australian Journal of Agricultural Research 16:743-755.

Ovalle, C., S. Arredondo, A. del Pozo, F. Fernández, J. Chavarría, and A. Augusto. 2010. Arrowleaf clover (Trifolium vesiculosum Savi.): a new species of annual legumes for high rainfall areas of the Mediterranean climate zone of Chile. Chilean Journal of Agricultural Research 70:170-177.

Ovalle, C., S. Arredondo, and O. Romero. 2006. Serradela amarilla (Ornithopus compressus) y 
Serradela rosada (O. sativus): dos nuevas especies de leguminosas forrajeras anuales para la zona mediterránea de Chile. Agricultura Técnica 66:196-209.

Ovalle, C., A. del Pozo, J. Avendaño, and F. Fernández. 2005. Adaptación, crecimiento y producción de nuevas leguminosas forrajeras anuales en la zona mediterránea de Chile. II. Comportamiento de las especies en suelos graníticos del secano interior subhúmedo. Agricultura Técnica 65:265-277.

Peoples, M.B., R.R. Gault, G.J. Scammell, B.S. Dear, J. Virgona, G.A. Sandral, J. Paul, E.C. Wolfe, and J.F. Angus. 1998. Effect of pasture management on the contributions of fixed $\mathrm{N}$ to the $\mathrm{N}$ economy of ley-farming systems. Australian Journal of Agricultural Research 49:459-474.

Richardson, A.E., L.A. Viccars, J.M. Watson, and A.H. Gibson. 1995. Differentiation of Rhizobium strains using the polymerase chain reaction with random and directed primers. Soil Biology and Biochemistry 27:515-524.

Sadzawka, A., M.A. Carrasco, R. Grez, M.L. Mora, H. Flores, and A. Reaman. 2006. Métodos de análisis recomendados para los suelos de Chile. Revisión 2006. Instituto de Investigaciones Agropecuarias, Centro Regional de Investigación La Platina, Santiago, Chile. Serie Actas INIA No 34.164 pp.

Ward, P.R., F.X. Dunin, and S.F. Micin. 2001. Water balance of annual and perennial pastures on a duplex soil in a Mediterranean environment. Australian Journal of Agricultural Research 52:203-209.

Ward, P.R. 2006. Predicting the impact of perennial phases on average leakage from farming systems in south-western Australia. Australian Journal of Agricultural Research 57:269-280. 